\title{
A Starvation Aspect Missing in Achebe's Book on the Nigerian Civil War
}

\author{
Wilson I. B. Onuigbo \\ Department of Pathology, Medical Foundation and Clinic, 8 Nsukka Lane, Enugu, Nigeria \\ *Corresponding Author: Wilson I. B. Onuigbo, Department of Pathology, Medical Foundation and \\ Clinic, 8 Nsukka Lane, Enugu, Nigeria
}

\section{EDITORIAL}

Nature performs wonders. Consider common crabs. Actually, they played an uncommon role as actors and actresses during the Nigerian Civil War! Thus, as Nature has it, crabs are created to provide secure homes for perilous parasites thereby causing a debilitating disease known as paragonimiasis! ${ }^{1}$ These parasitic dwellers are the offsprings of the adult worms whose official scientific name is Paragonimus uterobilateralis. What a jaw-breaking, though majestic, name?

Name calling, be it noted, has of late featured with more than a bang in Nigerian Newspapers. The debate has been the aftermath of Chinua Achebe's monumental autobiography entitled "There Was A Country". 2 On my own part, I wish to contribute to this ongoing debate. In short, let me join under the umbrella of happening to be a Nigerian scientist whose biography appeared in "World Who's Who in Science" precisely in 1968 while the Civil War was hotting up. ${ }^{3}$ Indeed, I would like to introduce a substantial scientific angle.

Angle, which is incontrovertible, will be viewed from a tripod consisting of (a) strict starvation, (b) crab crunching, and (c) perilous paragonimiasis! Let me explain. The stark scene of sorrowful suffering was set rather inexorably in that diminishing territory that the secessionist enclave became as the war continued. In fact, in the Okigwe locality, it came to such a sorry stage that famished families found solace in eating common crabs. Unfortunately, not only the prevailing hostile circumstance but also the incapacitating negligence by the fugitives led to the very cooking of the crabs being poorly undertaken. As a result, the Paragonimus parasites sojourning naturally inside these crabs were still very much alive when they gained ready entrance into the many beleaguered bodies!

Bodies were, in general, affected particularly in the lungs where the parasites grew and matured naturally. Alas! The resulting cough was coupled with copious bloody sputum or even frank bleeding. It was at this serious stage that an astute Igbo scientist surfaced. He was no other than the Specialist Physician, Prof. Chukuedu Nwokolo. Hospital consultancy and his wide reputation facilitated Nwokolo's contact with crowds of patients. ${ }^{4}$ This was what enabled him to recognize the difference between (a) the few Paragonimus patients whom he had seen personally prewar and (b) the postwar epidemic throng. However, the new illness merely mimicked tuberculosis, seeing that the patient's appearance was substantially significant. Thus, laboratory investigation of their sputum revealed the presence not of tuberculosis germs but of the specially shaped Paragonimus eggs.

Eggs endowed with this particular shape abounded and were being documented thoroughly. Lo and behold! The adult egglaying worms had never been identified within human beings. Little wonder that, as things stood in 1972, the puzzled Professor sought my help. I was then the Specialist Pathologist in charge of the Eastern Nigerian Regional Laboratory based at Enugu. In point of fact, he told me to be on the look out for the hitherto hidden adult worms.

Worms being targeted in this manner were to surface in the fullness of time. How? On 27/8/72, Dr Festus Nwako, a Specialist Paediatric Surgeon at the Teaching Hospital, Enugu, operated on an Igbo girl aged 8 years. She had lived in the notorious Okigwe area and 
was thereafter suffering from a lump in her abdominal wall. Both its removal and submission to me for diagnosis were effected routinely by way of an adequate container filled partly with the requisite formalin fluid. This aspect of the special laboratory investigation constituted the First Chapter.

Chapter 2 manifested truly in the form of "serendipity". This is a word defined in terms of "making fortunate and unexpected discovery by chance". Now, to continue, the ordinary step of cutting into the girl's specimen revealed that Paragonimus eggs were present. Therefore, what of the worms proper? In this context, Dr. J. Voelker, ${ }^{5}$ a German worm specialist, who was known for his worm work in Liberia, was doing research with Professor Nwokolo. Accordingly, by way of precaution, I gave him one half of the specimen so as to investigate it with a special microscope on 20/2/73. He found no worm. Nor did any worm come to light when the remaining half was handed over on 22/2/73. Meanwhile, the serendipity aspect manifested because I had the hunch that these worms might have gravitated into the fluid which still remained in the submission container. Consequently, I directed Mr. Edward Maduko, my Senior Laboratory Technician, to be careful as follows: (a) to retrieve the stored container, (b) to spin its contents, (c) to obtain the residue, (d) to prepare what is called a wax block, and (e) to submit the usual microscope slide.

Slide of excellence was expertly examined by me on 26th February, 1973. This fortunately revealed the elusive sexy couple - two adult Paragonimus worms! Yes! Husband and wife were uniquely exposed. Hence, in this most masterly manner, I became the World's discoverer of these wondrous worms. Subsequently, this discovery was co-authored with Surgeon Nwako and published in the 1974 September issue of the bilingual EnglishGerman Journal called Tropenmedizin und Parasitologie. ${ }^{6}$ The terse title was "Discovery of Adult Parasites of Paragonimus uterobilateralis in Human Tissue in Nigeria".

Nigeria was in this way hoisted up highly in the world literature of animal science. Remember that this came to light after the war had ended. Nevertheless, this story mirrors the undercurrents which must have been prevailing during the war and even afterwards. Indeed, the tip of the erstwhile iceberg of hostile malnutrition became more visible in this way. Thus, Prof. Nwokolo, who knew of only very few prewar sufferers of paragonimiasis, treated a deluge of 100 cases at Enugu within the 10 months period from November 1970 to August $1971 .^{7}$ Incidentally, he treated them successfully with the drug, Bithionol, and acknowledged its generous supply from the Center for Disease Control, Atlanta, Georgia, U.S.A. and the U.S.A.I.D. Tuberculosis Program.

Program of this international assistance was one important aspect of the Civil War. However, it pertained to a mere fraction, namely, the lucky victims who were treated successfully at Enugu. What of the rest of the incalculable totality of the exposed population who were also at risk? This means that the very well known deaths due to Kwashiorkor did not constitute the whole picture. Perhaps, even at this late time, when some counsel that the War should be forgotten, sociological survey may throw some light on death or disability associated with cough and bloody sputum in various communities with special reference to those who had sojourned in the Okigwe axis.

Be that as it may, it should be borne in mind that the genesis of this worm disease was grimly grounded on the strict starvation which the world acclaimed Chinua Achebe expatiated on both graphically and passionately. Accordingly, in conclusion, may this insider insight of mine be recognized as going another mile in that disastrous distance pertaining to the pernicious ill health captured in Achebe's well couched and convincing masterpiece.

\section{REFERENCES}

[1] Spencer H. Tropical pathology. NY: SpringerVerlarg, 1973, p 621-632.

[2] Achebe C. There was a country. 2012; Lond: Penguin Press.

[3] World Who's Who in Science. Marquis-Who's Who: Chicago: Illinois, 1968, p. 1285.

[4] Nwokolo C. Outbreak of Paragonimiasis in Eastern Nigeria. Lancet, 1972; 1:75-77.

[5] Voelker J. Morphologisch-taxionomische untersuchungen uber Paragonimus uterobilateralis (Trematoda, Troglotrematida) .... Tropenmed Parasitol. 1973; 24: 1-20. 
A Starvation Aspect Missing in Achebe's Book on the Nigerian Civil War

[6] Onuigbo WIB, Nwako FA. Discovery of adult parasites of Paragonimus uterobilateralis in Nigeria. Tropenmed Parasitol, 1974; 25:433436.
[7] Nwokolo C. Endemic Paragonimiasis in Eastern Nigeria: Clinical features and epidemiology of the recent outbreak following the Nigerian Civil War. Trop Geogr Med, 1972; 24: 138-147.

Citation: Wilson I. B. Onuigbo, Starvation Aspect Missing in Achebe's Book on the Nigerian Civil War. International Journal of Research Studies in Medical and Health Sciences. 2017;2(5):8-10.

Copyright: () 2017 Wilson I. B. Onuigbo. This is an open-access article distributed under the terms of the Creative Commons Attribution License, which permits unrestricted use, distribution, and reproduction in any medium, provided the original author and source are credited. 